\title{
MUSIC MUSEUM DESIGNING SOLUTIONS ACCORDING TO CULTURAL SUSTAINABILITY IN TABRIZ
}

\author{
Shahram Boluri Abr \\ Student Ma University Architecture، Jolfa Branch، Islamic Azad University، Jolf Iran \\ shahram.boluri@yahoo.com \\ Lachin Pahlyan Alamdari \\ A Faculty Member At Azad University Azarshahr \\ lachin_1981@yahoo.com
}

\begin{abstract}
Tabriz is the capital and largest city of Azerbaijan, an ancient city that has a great reputation and also city of innovations in Iran. But it is worth to discuss about the weakness point of this great city with thousands of years of culture and civilization. While for such a large city which have great artists, have not been established a worthy museum of them. Building the first music museum in the North West and in the largest city of it means in the Tabriz, meanwhile led to development of the tourism industry in this city and also caused a cultural and artistic place to be for those interested in art and music. The aim of such a museum in Tabriz, can be giving attention to Azerbaijani culture and traditional music, create an appropriate architectural atmosphere to become familiar with a variety of musical instruments, designing and categorize the galleries based on a variety of instruments, creating an appropriate architectural atmosphere to gather the music artists and their related instruments, designing the cultural centers inside the Museum like specialized music library and amphitheater. In the literature review to gather the relevant information in this field will perform by library research and using reliable sources such as books, papers, and thesis. With designing questions, finding uncertainties in the research topic with an indication of the need for research and in the following with performing the library and scientific studies as well as field studies, this all will led us to find a suitable place for the project and finally answer the research questions.
\end{abstract}

Keywords: Museum, Music, Azerbaijan, Designing, Tabriz

\section{INTRODUCTION}

Music word is from the Greek word Mousika and this word is derived from Muse which is the name of the protective Gad who guarding poetry and music of ancient Greece. Museum is meaning protective God. Such as the suffix \{one\} in the classic and romantic and dramatic words, and so on a suffix of ratio and attributed. But in the French word turns to prefix such as: Muzigu, Muzigan or Muzgan as well as the findings of this word in Persian language means Muzgan (Muzghun) and Muzghanjy which meaning music and Muzicchy is meaning stringer. Other interpretations of the word music is G conquered and A Maqsura which is abbreviation of Musigar in Arab word and in Arabic language is a combination of (Moses) means song and (Gey) means fun and enjoyable. According to the sayings the word of music in Iran became common from the Third century AH and the old philosophers believed that music is caused by the dynamic and motion of the heavens.

Also, this words refers to a song that it's a group of sequential and combination melodies. In any case, music is the art of expressing emotions through sounds and it mentioned that the most important factor of music is weight and sound. As well as art of combination of sounds in a tone that brings pleasure of 
The Turkish Online Journal of Design, Art and Communication - TOJDAC July 2016 Special Edition

revolution and expansion to the soul. Aristotle knew the music branch of mathematical science and Abu Ali Sina also has mentioned about music in mathematic part of the book of healing namely "Shifa".

By the way nowadays music is part of art science (or industry) and its worldwide subject that has very diverse and specialized sectors such: 1- Orchestral folk music, 2- Jazz music, 3- Local music, 4- Vocal music, 5- Instrumental music, 6- Religious music, 7- Folk music, 8- Architectural music, 9- Electronic music.

\section{THE NECESSITY OF RESEARCH}

Tabriz is the capital and largest city of Azerbaijan, an ancient city full of history and prestige that also its city of innovations in Iran which including the construction of Iran's first public reading house in 1312, the first modern school, first photograph studio and other purposes. During the centuries of history (3500 years) which in the historical literature and resources close to 65 names and also in the other resources about 31 name have been defined to Tabriz. Despite the description of the history and culture of Azerbaijan and Tabriz, some of them mentioned in the above text; it is worthy to discuss about the weakness point of this great city with thousands of years of culture and civilization. Because this city was cultural city which has different artists in different fields such as music, theater, cinema and other arts. But for a city with such great artists as professor Eqbal Azar, Fakhr al-Din and other masters of music has not been built any museum that they deserve it and the responsible authorities in the Tabriz cultural legacy and tourism during these years had no plan to build the art museum such as Music Museum in Tehran or Kerman in Iran. On the other hand, except Tehran's Music Museum, Professor Saba Museum and Kerman there is no music museum in the other cities of Iran. So, building the first music museum in the North West and in the largest city of it means in the Tabriz, collecting the country music artists works specially in Azerbaijan, the main bases for growth and prosperity of young talents in this vast territory of Iran will be provided while developing the tourism industry, create a suitable cultural and artistic place to those interested in art and music.

\section{AZERBAIJAN CULTURE}

Azerbaijan is a famous name in the history of Iran. In historical documents and resources, from remaining old inscriptions to Torah and Avesta and ancient Greek historian book such Xenophon, Herodotus and Estrabon and other historians and researchers all have agreed on this point that; Mede people (Azerbaijan) on origin and national and cultural identity and also history of the language, religion and customs tools are similar to other ethnic groups and all are unique and common.

One of the precious figures from this area can be known as Eqbal Azar as the kind of singing artists in Iran, Fakhr al-Din and other Professors can be mentioned.

\section{Music}

According to Iranian saying, the word of music is derived from the name of a bird called Phoenix or Musigar. Music have been derived from Greek goddess of poetry and fine arts and according to the Greeks saying this goddess had nine daughters and each of them was creative in various science and technologies from poetry, manner, song, hymns and so on and they were called as Muzis, that is why the Arab word (Musigar) or (Musigur) means the singer and the knowledge of musician is called Music.

\section{Summary Of Iranian Music History}

Iranian traditional music, including equipment, melodies and songs in thousands of years from BC to the present have been going on between Iranian people and which one is more pleasant and easier to understand is available today. A large part of Central Eurasia, Afghanistan, Pakistan, Azerbaijan, Armenia and Turkey influenced by this music and each of them for their part, have had an impact on development and growth of this music. Before to discuss briefly about the history of music in Iran should pay attention to several points: First, ancient Iran was a vast country with big territory which covers 30 
countries, and consequently it had many peoples from many nations together and help each other to progress and achievements and it was not alone. Through the various type of music in national format and based on rules and regulations different nations and ethnic groups were formed. Revolution, civilizations and historical events have laid the foundations in traditional and national music major contribution.

Iran in terms of music has historical value and it's worthy to give attention. Professional historiography is a new subject while Iran's history from ancient times until today has not been written. But except for the mentioned reason, there are other reasons for it too. Since music is the oral art, compared with other arts, it have very less and late historic written. Iran unstable conditions due to the continuous influx of foreign tribes and nations and also internal ravages led to this situation and also if there was enough evidence by the way wiped out and left. According to some Orient historians Iran's music history during the Achaemenian era have estimated and one of the seven languages of that period, people have to know it was probably the music and they used those languages for Mourning for Siavash. However from that time, detailed information is not available but the Gathas hymns were sung as harmonious but in Iran's old religion, music had not so much importance. But secular (non-religious) music such as dancing and singing was common. After Alexander's invasion of Iran in the Seleucid and Parthian era, Iran was under the influence of Greek civilization and great developments in field of music had happened. But in fact Iran's music's foundation dates back to the Sassanid era and original documents of Iranian Persian music belonging to this era. About Khosrow Parviz's king and his glorious empire much has been said, but it worth to mention that in this era the musicians have supported from his side; some of the most important musicians of this period such Ramtin, Bamshad, Barid, Nakisa Azad and Sarkesh can be mentioned that their names still remains. One of the most prominent musicians of this era was Barid and many stories about his skill in playing and composing have quoted later. Arranging and organizing musical system, and also seven authority structure known as Khosrovani, thirty Mugam and three hundred sixty melodies attributed to him. Today is not well understood that what was that Mugam and songs. But some of this songs' name listed by the Islamic writers names such as Kine Iraj and Kine Siyavash was perhaps referring to historical events or the names such Shirin's Garden or Shahriyar Garden are showing the majestic of the palace, as well as they were using the names such spring green and bright lights, but about the creating the song in that era and their theoretical principles there is no information available. Of course in the study of pre-Islamic period one of our prestigious sources as bas reliefs and statues and the container is obtained that it belongs to 1500 year before Christ begins. Ancient statues found in spheres that obtained in Susa, one music instrument have obtained which is like Tanbour. It represents a melodic instrument in that time. In the carvings of Taq-e Bostan, harpist musicians group and wind musical instruments also has been seen. Most of information's about Iran's pre-Islamic history limited to the books and poems remains from first century of the Islamic era and there is no information about applied music and strict enforcement of music from this era. Sassanid era is the main music core which from this era Islamic civilization music has grown, after Islam a brief stop happened in Iran's music, and after a few years, was altered. But in the period after the Arab conquest of Iran until the end of Rashedin Caliphs who ruled in the first century of Islamic period (from eleven to forty-one $\mathrm{AH}$ ), a variety of music was forbidden. With the beginning of the rule of the Umayyad, Music became more freedom, and from this time until the Abbasid periods shows a peak in theoretical and practical music of Iran and Islam.

At this time people like Ibn Sina, Nasir al-Din al-Tusi, Ibn Zyleh, Ibn Safi, Abdul Qadir Maraghi, Abul Faraj Isfahani, Abraham, Isaac, Moses, Qutb al-Din Mahmoud Shirazi and many other people in music theory and in practice have flourished and there is their books and treatises on music. In general, before Islam music should be considered as practical music because the regulation and principals were not found between the voice and tones. But in the Islamic period, according to the rules of music that the Greek philosophers had designed it a movement emerged in the Iranian music. During the Safavid and Qajar periods music was under the authority of the government and fell away from society. But religious formation of music in a morality play and dramatic performances by musicians and poets also continued. 
The Turkish Online Journal of Design, Art and Communication - TOJDAC July 2016 Special Edition

But its separated from the music which was used in Islamic times, and music formation became more Iranians. The importance of music during the Safavid era can be observed in the great House music room Ali Qapvr and Chehelsotoon Palace. This trend reached its peak of perfection in the Qajar period and another system had emerged during the Safia period had completed and by virtuosos of that time orally delivered to the disciples of such instruments like cittern, tar, flute and fiddle. At the same time in the Qajar period, modern musical notes reached to Iran. Iran masters of music and their oral tradition called Row was turned to musical notes and from Nasser period onwards it also influenced by other cultures and finally music found more creative. The new era began with the start of the twentieth century due to the impact of the West music between the people and new prosperity for education has started. In the early 1930s was established conservatory of Music in Tehran and Western training base was started, completed symphony orchestra and choir were organized alongside the traditional Iranian music concerts which was held by Ali-Naqi Vaziri's efforts.

After World War II various musical groups in different fields, as well as numerous festivals and international artists was held in 1970 in Iran and the capital experienced dynamical musical life. The impact of radio and television in this case was quite striking. Conservatory of music and also national conservatory of music, music faculty of Tehran University have trained many students majoring in musicology and create music with Western style and traditional Iranian music and great leaders appeared in Iran's music scene which could perform valuable services for the country such as: Gholamhossein Darvish (1921_ 1872) Ruhollah Khalegi (1965_1906) Professor Abolhassan Saba (1957_1902) Professor Ali Naqi Vaziri, Mehdi Berkshly and musicologist Mohammad Taghi Masoudieh.

\section{Music Museum of Azerbaijan}

Azerbaijan music refers to the traditional folk music. Azerbaijani artists with their creativity, created a unique music. Those people who interested in this type of music and singing with Azerbaijani language (Turkish language), called Ashik. Ashik in praise of Azerbaijan and its great courage, celebration and mourning, sings beautiful poems along with the music of Azerbaijan and they always interested by people and they existed among people of Turkish origin from the era before Islam.

Azerbaijani music consists of two types or characteristics which are divided into different modes and sources. Usually the type of musical instrument of Azerbaijan, origin and types of music lovers together somewhat different, although many are both friendly. Many musicians of Azerbaijan familiar to both types of music could create great artwork in the form of Opera, Ballet and Symphony music. One of the most important musical genres such as music pub Azerbaijan, Azerbaijani tar performing art Balaban, Naqara, bağlama and Garmon can be mentioned.

\section{Museum}

Museum is a permanent institution without financial goals that has opened its doors to the public, In order to preserve the cultural heritage and promoting artistic and cultural community in different ways, especially through educational and recreational displays collections of art, history, science, technology etc. works for the public. (Nafisi, 2003, 11)

\section{History of Museum Establishment in Iran and Azerbaijan}

About the History of Museum in Iran must be stated that collecting and storing valuables in Iran with an incentive to maintain personal works and were more private mode. The first samples can be seen during the Achaemenid dynasty and with the formation of an independent government in Iran which was purely private and it is only used by philosophers and kings of the time was formed 120 years ago, the first example can be seen in the reign of Mohammad Ali Shah Qajar king which in his period some part of Golestan Palace become Museum of instruments, valuable things and royal stuff and lords have visited there. In 1295 AH when, Murtaza Khan Mmtazalmlk actually was responsible for the official aristocracy 
and on the basis of this thinking in the Education and Religious Affairs the small department called Branch of antiquities was established which was later renamed to Opal Circle, and finally under the supervision of the department of education continued its activities. According to antiquities law that was passed in 1299, all drilling and exploration activities came under the direct supervision of the government and the French concession to discover the antiquities on the ground drilling for many years was canceled. Instead, the Iranian government accepts to establish a museum of antiquities and a national library in Tehran and to headed up it three times and every five years to the French delegate. In the year 1310 (AH) Hijri Shamsi with the discovery of ancient relics in Persepolis Persepolis Museum was established to preserve these objects. In 1314 (AH) Hijri Shamsi the building of the Museum of Anthropology of Iran was founded, after 20 years, the Museum of Anthropology in St. Armenians (Bu Ali) opened to provide better anthropology museum next to the palace Abyad Golestan Palace, the oldest in the country transferred Museum. (Helper, 2010, 29)

\section{Architecture And Music}

All the arts are cross-linked together, because they are the source of all manifestations of beauty. The beauty of the architecture and sculpture as the ratio of length, width and height is happening. In a face proportions that create beauty. Sometimes the beauty of the colors fit together which in performing also a set of optical frequencies creates pleasant proportions. The ratio of sounds lead to beauty. Proportion sometimes is in the visual aspect and sometimes in the auditory attention, visual and tactile also have mentioned. Therefore, all art has an aspect and it is already designed with the geometry of our heart.

Beyond a line segment of length one, only find a spot that gives the most succinct proportion to us. In all the arts brevity is one of the wagers. At the point where we find the entire segment in large part its equal to ratio of large section to the small section, these ratios, gives us Phi number which it's called the Divine Proportion. It means that we are faced with this monotheistic rule and everything originates from a real aspect and real unity of the world is beautiful for us. After a number of one there are number two and three. All steps of music are result of these two numbers. When we get into the rhythm section, is obtained by multiplying the number two and three and when the rhythm is complex, it's the sum of these two numbers (of course with different respectively). When we show we are moving from one point to the monotheistic world. First, we are faced with two and three. In the architecture also we dealing with optical frequencies that define the length, width and height and when these three is in the most succinct formation, you can feel the beauty and this proportions exist in the most of the great works of architecture. Interestingly, this proportions are exists in the human body, anatomy of birds and trees and everywhere and there are equally divine.

\section{CONCLUSION}

Due to the specific and historical conditions of Tabriz in terms of cultural and musical condition, results which obtained in the design and can be considered in the design of the museum are as follows:

1- Paying attention to the history of music and traditional centers such as Tabriz destroyed concert named Ark Ali Shah.

2- Respect and attention to the Azerbaijani music

3- Building such a museum can help to preserve artists' works.

4- Assigning the largest gallery to Stringed Music because of registration of Tar in UNESCO as traditional Azeri instrument and having valuable Azeri artists in the field.

5- assigning some part of the galleries to Azerbaijani artists related to that part due to introduce the culture and authentic Azerbaijani artists

6- Considering the cold mountain climate in designing the museum with minimum openings.

7- Establishment of such a museum in the country and in this region of West Azerbaijan raises the level of musical culture of enthusiasts. 


\section{REFERENCES}

Ahmed, Syed Hussam al-Din, 2010, the transition to the flowers, books, Tehran

Benesh, T., 1995, knowledge of Persian Music, University of Art, Tehran

Falamaki, M., 2008, architecture, music, publishing space, Tehran

Imrani, rafig, translator Majid Timorese far, in 1999, a long history of Azerbaijani music, publishing Akhtar, Tabriz

Khalegi, R., 1983, the history of Iranian music, publishing Safi Ali Shah, Tehran

Khamachy, B., 2009, my city of Tabriz, publishing Call of Shams of Tabriz

Noshen dokht, n., 2003, museum, cultural Nyras Nations, the Organization of study and drafting (side), Tehran

Sardari Nia, 2005, Survey of the History of Azerbaijan, publishing Akhtar, Tabriz

Yavari, H., Rajabi, Zainab, 2010, Introduction to Museum of Iran, The Mahkameh, Tehran 